\title{
PENGARUH PERBANDINGAN TEPUNG BERAS DENGAN PASTA UBI JALAR UNGU (Ipomoea batatas L. Poir) TERHADAP KARAKTERISTIK CENDOL
}

\author{
The Comparison Effect of Rice Flour and Purple Sweet Potato (Ipomoea batatas L. Poir) Paste on \\ the Characteristics of Cendol
}

\author{
Putri Ayu Wulandari1), I Made Sugitha $^{2)}$, Ni Made Indri Hapsari Arihantana ${ }^{2)}$ \\ ${ }^{1}$ Mahasiswa Program Studi Ilmu dan Teknologi Pangan, Fakultas Teknologi Pertanian, Unud \\ ${ }^{2}$ Dosen Program Studi Ilmu dan Teknologi Pangan, Fakultas Teknologi Pertanian, Unud \\ Kampus Bukit Jimbaran, Badung-Bali
}

\begin{abstract}
This research was aimed to identify the comparison effect of rice flour and purple sweet potato (Ipomoea batatas L. Poir) paste on the characteristics of cendol and to identify the right ratio of rice flour and purple sweet potato paste to produce cendol with the best characteristics. Completely randomized design was used in this research with treatment ratio of rice flour and purple sweet potato paste which consisted of 6 levels : 50\%:50\%, 40\%: 60\%, 30\%: 70\%, 20\%:80\%, 10\%:90\%, and 0\%: $100 \%$. Each treatment was repeated 3 times, resulting in 18 experimental units. The data were then analyzed with analysis of variance and if the treatment had an effect on the variable, the Duncan test was performed. The results showed that rice flour and purple sweet potato paste ratio had significant effect on water content, ash content, crude fiber content, antioxidant activity, anthocyanin, color, texture, flavor, taste, and overall acceptance of cendol. Making purple sweet potato cendol without using rice flour resulted the best characteristic under the following criteria: $89,47 \%$ water content, 0,14\% ash content, 1,44\% crude fiber content, 93,42 $\mathrm{mg} / \mathrm{mL}$ antioxidant activity, $1,37 \mathrm{mg} / 100 \mathrm{~g}$ anthocyanin, dark purple and very liked color, texture chewy and liked, flavor typical of purple sweet potato and liked, taste very typical of purple sweet potato and liked, and overall acceptance very liked.
\end{abstract}

Keyword : cendol, purple sweet potato paste, rice flour

\section{PENDAHULUAN}

Cendol merupakan salah satu makanan khas Indonesia yang bahan baku utamanya terbuat dari tepung beras dan tepung hunkwe yang dicampur dengan air kemudian dipanaskan hingga menjadi padat akibat gelatinisasi pati (Patmawati, 2011). Cendol memiliki tekstur yang kenyal, berbentuk lonjong dan umumnya berwarna hijau, serta biasa disajikan dengan tambahan santan dan larutan gula merah (Candraningsih, 1997). Kandungan gizi dalam 100 gram cendol adalah energi 95,08 Kal, karbohidrat 8,25 g, protein 1,21 g, dan lemak 6,44 g (Anon., 2001 dalam Ubaedillah, 2008). Tepung beras merupakan tepung yang diperoleh dari penggilingan atau penumbukan beras serta mengandung energi sebesar 364 Kal, karbohidrat $80 \mathrm{~g}$, protein $7 \mathrm{~g}$, lemak 0,5 $\mathrm{g}$, kalsium $5 \mathrm{mg}$, fosfor $140 \mathrm{mg}$, dan zat besi 0,8 mg (Direktorat gizi, 2004), sedangkan tepung hunkwe merupakan tepung yang terbuat dari pati kacang hijau (Vigna radinata L.) serta mengandung energi sebesar $364 \mathrm{Kal}$, karbohidrat 83,5 g, protein 4,5 g, lemak $1 \mathrm{~g}$, kalsium $50 \mathrm{mg}$, fosfor $100 \mathrm{mg}$, dan zat besi 1 mg (Direktorat gizi, 1979). Karbohidrat

*Korespondensi Penulis:

E-mail: puputvanilla@gmail.com ${ }^{1)}$ 
tersebut terdiri dari amilosa 28,8\% dan amilopektin 71,2\% (Muchtadi dkk, 2010). Kandungan amilopektin yang tinggi ini mampu menjadikan tekstur cendol menjadi kenyal (Ubaedillah, 2008).

Meningkatnya kesadaran masyarakat akan pentingnya hidup sehat, maka kecenderungan konsumen dalam mengkonsumsi pangan mempertimbangkan pengaruh pangan tersebut terhadap kesehatan. Penambahan komponen bioaktif dalam pembuatan cendol dibutuhkan agar dapat menjadikan cendol sebagai pangan fungsional, salah satunya yaitu antioksidan. Bahan pangan yang diketahui sebagai sumber antioksidan dan bahan baku lokal yang mudah ditemui yaitu ubi jalar ungu.

Ubi jalar ungu (Ipomoea batatas $L$. Poir) merupakan salah satu jenis umbiumbian yang potensial di Indonesia, baik produksi maupun manfaatnya. Ubi jalar ungu dapat dijadikan bahan baku dalam olahan pangan karena kandungan gizinya yang kaya akan vitamin, mineral, serat, dan merupakan sumber karbohidrat dan sumber kalori (Ginting et al., 2011). Menurut Apriliyanti (2010), kandungan amilosa pada ubi jalar ungu sebesar 17,5-20\%, lebih rendah dibanding dengan kadar amilosa tepung beras yaitu 26,58\% (Supriyadi, 2012) sehingga dapat menggantikan tepung beras dalam pembuatan cendol. Semakin rendah kadar amilosa maka membuat tekstur semakin kenyal. Ubi jalar ungu mengandung pigmen alami berwarna ungu yang disebut antosianin yang memiliki aktivitas antioksidan yang dapat menghentikan reaksi berantai pembentukan radikal bebas sehingga berperan dalam mencegah terjadinya penuaan dini, kanker, dan penyakit-penyakit degeneratif (Hardoko et al., 2010). Warna ungu yang terdapat pada ubi jalar ungu juga dapat dijadikan sebagai pewarna alami dalam pembuatan cendol.

Tujuan penelitian ini adalah untuk mengetahui pengaruh perbandingan tepung beras dengan pasta ubi jalar ungu terhadap karakteristik cendol dan mengetahui perbandingan yang tepat untuk menghasilkan cendol dengan karakteristik terbaik, sehingga dapat menjadikan cendol sebagai pangan fungsional terutama karena kandungan antioksidannya.

\section{METODE PENELITIAN}

\section{Tempat dan Waktu Penelitian}

Penelitian ini dilaksanakan di Laboratorium Pengolahan Pangan, Laboratorium Analisis Pangan, dan Laboratorium Rekayasa Proses dan Pengendalian Mutu Fakultas Teknologi Pertanian, Universitas Udayana. Pelaksanaan penelitian ini dilakukan pada bulan Juli sampai dengan bulan September 2018.

\section{Bahan dan Alat}

Bahan-bahan yang digunakan dalam melaksanakan penelitian ini terdiri dari bahan baku dan bahan kimia. Bahan baku yang digunakan adalah ubi jalar ungu yang diperoleh dari swalayan Tiara Dewata Denpasar, serta tepung beras dan tepung hunkwe yang diperoleh dari UD. Fenny Denpasar. Bahan kimia yang digunakan adalah $\mathrm{NaOH}, \mathrm{H}_{2} \mathrm{SO}_{4}$, aquades, alkohol, metanol, 1,1-diphenyl-2-picrylhydrazyl (DPPH), $\mathrm{HCl}, \mathrm{KCl}, \mathrm{Na}-$ Sitrat, asam sitrat, kertas saring, alumunium foil (Klin Pak) serta kertas Whatman no. 42.

Alat yang digunakan dalam proses pembuatan cendol ubi ungu adalah panci, baskom, cetakan cendol, saringan, kompor gas, timbangan digital, sendok pengaduk, blender, pisau, talenan dan gelas ukur. Alat yang digunakan untuk analisis antara lain lumpang, cawan alumunium, desikator, cawan porselin, oven, timbangan analitik, pinset, muffle, spatula, erlenmeyer, gelas beaker, gelas ukur, tabung reaksi, pipet volume, pompa karet, labu takar, corong, vortex, waterbath, dan spektrofotometer. 


\section{Rancangan Percobaan}

Rancangan percobaan yang digunakan adalah Rancangan Acak Lengkap (RAL) yang terdiri dari 6 perlakuan perbandingan tepung beras dan pasta ubi jalar ungu, yaitu 50\% : $50 \%$, 40\% : 60\%, 30\% : 70\%, 20\% : $80 \%$, 10\%: $90 \%$, dan 0\% : 100\%. Masing-masing perlakuan diulang sebanyak 3 sehingga diperoleh 18 unit percobaan. Data yang diperoleh kemudian dianalisis menggunakan Analysis of Variance (ANOVA) dan apabila terdapat pengaruh antar perlakuan terhadap variabel yang diamati, maka dilanjutkan dengan uji Duncan (Gomez dan Gomez, 1995).

\section{Pelaksanaan Penelitian}

Proses pembuatan cendol ubi jalar ungu meliputi beberapa tahap, yaitu:

1. Pembuatan Pasta Ubi Jalar Ungu

Pembuatan pasta ubi jalar ungu diawali dengan sortasi ubi jalar ungu, kemudian dicuci dengan air bersih. Setelah itu ubi jalar ungu dikukus selama 30 menit, kemudian didinginkan dan dikupas kulitnya. Selanjutnya diblender sampai tekstur menjadi halus dan lembek seperti bubur (Susilowati,
2010). Pasta ubi jalar ungu yang sudah jadi selanjutnya digunakan sebagai campuran dalam pembuatan cendol.

\section{Pembuatan Cendol Ubi Jalar Ungu}

Pembuatan cendol diawali dengan menimbang bahan baku yang terdiri dari tepung hunkwe, tepung beras, pasta ubi jalar ungu, dan air sesuai perlakuan. Selanjutnya semua bahan dicampur dan diaduk dalam panci hingga adonan merata. Setelah merata, adonan dipanaskan diatas kompor sampai timbul gelembung-gelembung pada suhu 80$85^{\circ} \mathrm{C}$ dan terbentuk adonan kental yang terjadi akibat gelatinisasi pati. Pemanasan dilakukan selama 10 menit dan dihitung setelah terjadinya proses gelatinisasi, sesuai dengan perlakuan terbaik dalam penelitian Chandra (2008). Selanjutnya dicetak menggunakan cetakan cendol dengan cara ditekan. Hasil yang keluar dari cetakan ditampung dalam wadah yang berisi air dingin.

Formula pembuatan cendol menurut Ubaedillah (2008) yang dimodifikasi dapat dilihat pada Tabel 1.

Tabel 1. Formula cendol perbandingan tepung beras dengan pasta ubi jalar ungu

\begin{tabular}{clcccccc}
\hline No. & Komposisi bahan & \multicolumn{7}{c}{ Perlakuan } \\
\cline { 3 - 7 } & & P1 & P2 & P3 & P4 & P5 & P6 \\
\hline 1. & Tepung beras (\%) & 50 & 40 & 30 & 20 & 10 & 0 \\
2. & Pasta ubi ungu (\%) & 50 & 60 & 70 & 80 & 90 & 100 \\
3. & Tepung hunkwe (\%) & 200 & 200 & 200 & 200 & 200 & 200 \\
4. & Air (\%) & 1200 & 1200 & 1200 & 1200 & 1200 & 1200
\end{tabular}

Keterangan : Persentase berdasarkan jumlah tepung beras dan pasta ubi jalar ungu (100 g)

Sumber : Ubaedillah (2008) yang dimodifikasi

\section{Variabel yang diamati}

Variabel yang diamati dalam penelitian ini adalah kadar air dengan metode pengeringan, kadar abu dengan metode pengabuan, kadar serat kasar dengan metode hidrolisis asam dan basa (Sudarmadji et al., 1997), aktivitas antioksidan dengan metode DPPH (Novindar, 2010), antosianin (Giusti dan Worlstad, 2001), serta sifat sensoris meliputi warna, aroma, tekstur, rasa, dan penerimaan keseluruhan menggunakan uji hedonik dan uji skoring (Soekarto, 1985). 


\section{HASIL DAN PEMBAHASAN}

Hasil analisis kadar air, kadar abu, kadar serat kasar, aktivitas antioksidan berdasarkan $\mathrm{IC}_{50}$, dan antosianin dari bahan yang digunakan dapat dilihat pada Tabel 2.

Tabel 2. Nilai rata-rata kadar air, kadar abu, kadar serat kasar, aktivitas antioksidan berdasarkan $\mathrm{IC}_{50}$, dan antosianin dari tepung beras, tepung hunkwe, dan pasta ubi jalar ungu.

\begin{tabular}{lccccc}
\hline \multicolumn{1}{c}{ Bahan } & $\begin{array}{c}\text { Kadar } \\
\text { Air }(\%)\end{array}$ & $\begin{array}{c}\text { Kadar } \\
\text { Abu }(\%)\end{array}$ & $\begin{array}{c}\text { Kadar Serat } \\
\text { Kasar }(\%)\end{array}$ & $\begin{array}{c}\text { Aktivitas antioksidan } \\
\text { berdasarkan } \mathrm{IC}_{50} \\
(\mathrm{mg} / \mathrm{mL})\end{array}$ & $\begin{array}{c}\text { Antosianin } \\
(\mathrm{mg} / 100 \mathrm{~g})\end{array}$ \\
\hline Tepung Beras & 13,14 & 0,41 & 2,11 & - & - \\
Tepung Hunkwe & 13,80 & 0,13 & 1,66 & - & - \\
Pasta Ubi Jalar Ungu & 67,28 & 1,34 & 4,22 & 15,82 & 4,00 \\
\hline
\end{tabular}

Keterangan : Tanda (-) menandakan tidak dilakukan analisis.

Tepung beras mengandung kadar air, kadar abu, dan kadar serat kasar masingmasing $13,14 \%, 0,41 \%$, dan $2,11 \%$. Kandungan pada tepung hunkwe masingmasing $13,80 \%, \quad 0,13 \%$, dan 1,66\%, sedangkan kandungan pada ubi jalar ungu masing-masing $67,28 \%, 1,34 \%$, dan $4,22 \%$.
Ubi jalar ungu juga mengandung aktivitas antioksidan berdasarkan nilai $\mathrm{IC}_{50} \quad \mathbf{1 5 , 8 2}$ $\mathrm{mg} / \mathrm{mL}$, dan antosianin $4 \mathrm{mg} / 100 \mathrm{~g}$. Hasil analisis kadar air, kadar abu, kadar serat kasar, aktivitas antioksidan, dan antosianin pada cendol ubi ungu dapat dilihat pada Tabel 3.

Tabel 3. Nilai rata-rata hasil analisis kadar air, kadar abu, kadar serat kasar, aktivitas antioksidan berdasarkan $\mathrm{IC}_{50}$, dan antosianin pada cendol ubi ungu

\begin{tabular}{lccccc}
\hline Perlakuan & $\begin{array}{c}\text { Kadar } \\
\text { Air }(\%)\end{array}$ & $\begin{array}{c}\text { Kadar } \\
\text { Abu }(\%)\end{array}$ & $\begin{array}{c}\text { Kadar Serat } \\
\text { Kasar }(\%)\end{array}$ & $\begin{array}{c}\text { Aktivitas } \\
\text { Antioksidan } \\
\text { berdasarkan IC } 50 \\
(\mathrm{mg} / \mathrm{mL})\end{array}$ & $\begin{array}{c}\text { Antosianin } \\
(\mathrm{mg} / 100 \mathrm{~g})\end{array}$ \\
\hline P1(50:50) & $86,72 \pm 0,71 \mathrm{c}$ & $0,09 \pm 0,00 \mathrm{c}$ & $1,25 \pm 0,07 \mathrm{c}$ & $184,32 \pm 16,06 \mathrm{a}$ & $0,16 \pm 0,00 \mathrm{~d}$ \\
P2(40:60) & $87,50 \pm 0,82 \mathrm{bc}$ & $0,09 \pm 0,00 \mathrm{c}$ & $1,31 \pm 0,07 \mathrm{bc}$ & $170,57 \pm 5,51 \mathrm{ab}$ & $0,16 \pm 0,00 \mathrm{~d}$ \\
P3(30:70) & $88,51 \pm 0,88 \mathrm{ab}$ & $0,10 \pm 0,01 \mathrm{c}$ & $1,37 \pm 0,05 \mathrm{ab}$ & $155,24 \pm 15,01 \mathrm{~b}$ & $0,16 \pm 0,00 \mathrm{~d}$ \\
P4(20:80) & $88,82 \pm 0,32 \mathrm{a}$ & $0,10 \pm 0,00 \mathrm{bc}$ & $1,40 \pm 0,01 \mathrm{a}$ & $126,43 \pm 11,68 \mathrm{c}$ & $0,80 \pm 0,02 \mathrm{c}$ \\
P5(10:90) & $89,07 \pm 0,32 \mathrm{a}$ & $0,12 \pm 0,02 \mathrm{~b}$ & $1,42 \pm 0,02 \mathrm{a}$ & $110,57 \pm 10,33 \mathrm{~cd}$ & $1,00 \pm 0,12 \mathrm{~b}$ \\
P6(0:100) & $89,47 \pm 0,31 \mathrm{a}$ & $0,14 \pm 0,02 \mathrm{a}$ & $1,44 \pm 0,03 \mathrm{a}$ & $93,42 \pm 8,68 \mathrm{~d}$ & $1,37 \pm 0,05 \mathrm{a}$ \\
\hline
\end{tabular}

Keterangan : Nilai rata - rata yang diikuti oleh huruf yang berbeda pada kolom yang sama menunjukkan berbeda nyata $(\mathrm{P}<0,05)$.

\section{Kadar Air}

Hasil sidik ragam menunjukkan bahwa perbandingan tepung beras dengan pasta ubi jalar ungu berpengaruh nyata $(\mathrm{P}<0,05)$ terhadap kadar air cendol ubi ungu. Tabel 3 menunjukkan kadar air cendol ubi ungu tertinggi diperoleh pada perlakuan P6 yaitu $89,47 \%$ serta berbeda tidak nyata dengan perlakuan P3, P4, dan P5. Kadar air terendah diperoleh pada perlakuan P1 yaitu $86,72 \%$ serta berbeda tidak nyata dengan perlakuan P2. Peningkatan kadar air terjadi seiring dengan meningkatnya penambahan pasta ubi jalar ungu, hal ini disebabkan karena kadar air pasta ubi jalar ungu sebesar $67,28 \%$, lebih tinggi dibanding dengan kadar 
air tepung beras yaitu $13,14 \%$. Kadar air merupakan karakteristik yang sangat penting pada bahan pangan karena dapat mempengaruhi tekstur suatu produk. Semakin tinggi kadar air yang terkandung dalam bahan maka akan membuat tekstur produk menjadi semakin lembek dan tidak keras.

\section{Kadar Abu}

Hasil sidik ragam menunjukkan bahwa perbandingan tepung beras dengan pasta ubi jalar ungu berpengaruh nyata $(\mathrm{P}<0,05)$ terhadap kadar abu cendol ubi ungu. Tabel 3 menunjukkan bahwa kadar abu cendol ubi tertinggi diperoleh pada perlakuan P6 yaitu $0,14 \%$. Kadar abu terendah diperoleh pada perlakuan P1 yaitu 0,09\% serta berbeda tidak nyata dengan perlakuan P2, P3, dan P4. Peningkatan kadar abu terjadi seiring dengan meningkatnya penambahan pasta ubi jalar ungu, hal ini disebabkan karena kadar abu pasta ubi jalar ungu sebesar 1,34\%, lebih tinggi dibanding dengan kadar abu tepung beras yaitu $0,41 \%$.

\section{Kadar Serat Kasar}

Hasil sidik ragam menunjukkan bahwa perbandingan tepung beras dengan pasta ubi jalar ungu berpengaruh nyata $(\mathrm{P}<0,05)$ terhadap kadar serat kasar cendol ubi ungu. Tabel 3 menunjukkan kadar serat kasar cendol ubi ungu tertinggi diperoleh pada perlakuan P6 yaitu 1,44\% serta berbeda tidak nyata dengan perlakuan P3, P4, dan P5. Kadar serat kasar terendah diperoleh pada perlakuan P1 yaitu 1,25\% serta berbeda tidak nyata dengan perlakuan P2. Peningkatan kadar serat kasar terjadi seiring dengan meningkatnya penambahan pasta ubi jalar ungu, hal ini disebabkan karena kadar serat kasar pasta ubi jalar ungu sebesar 4,22\%, lebih tinggi dibanding dengan kadar serat kasar tepung beras yaitu $2,11 \%$ sehingga semakin banyak konsentrasi ubi jalar ungu yang digunakan maka semakin tinggi pula kadar serat kasar yang terkandung di dalam cendol ubi ungu.

\section{Aktivitas Antioksidan (IC50)}

Hasil sidik ragam menunjukkan bahwa perbandingan tepung beras dengan pasta ubi jalar ungu berpengaruh sangat nyata $(\mathrm{P}<0,01)$ terhadap aktivitas antioksidan cendol ubi ungu. Tabel 3 menunjukkan aktivitas antioksidan berdasarkan nilai $\mathrm{IC}_{50}$ tertinggi diperoleh pada perlakuan $\mathrm{P} 1$ yaitu $184,32 \mathrm{mg} / \mathrm{mL}$ serta berbeda tidak nyata dengan perlakuan P2. Nilai $\mathrm{IC}_{50}$ terendah diperoleh pada perlakuan P6 yaitu 93,42 $\mathrm{mg} / \mathrm{mL}$ serta berbeda tidak nyata dengan perlakuan P5. $\mathrm{IC}_{50}$ (Inhibition Concentration) merupakan konsentrasi senyawa antioksidan yang dibutuhkan untuk mampu menghambat radikal bebas sebesar 50\%. Semakin kecil nilai $\mathrm{IC}_{50}$ maka semakin aktif ekstrak atau fraksi uji tersebut sebagai senyawa penangkap radikal bebas.

Nilai $\mathrm{IC}_{50}$ yang tinggi menunjukkan kemampuan antioksidan yang rendah, sebaliknya nilai $\mathrm{IC}_{50}$ yang rendah menunjukkan kemampuan antioksidan yang tinggi. Semakin banyak penambahan pasta ubi jalar ungu maka kemampuan antioksidan cendol ubi ungu semakin meningkat. Hal ini disebabkan karena kandungan senyawa antioksidan yang terkandung pada ubi jalar ungu tersebut. Menurut Hardoko et al. (2007), ubi jalar ungu memiliki aktivitas antioksidan yang berperan penting bagi tubuh karena dapat menghentikan reaksi berantai pembentukan radikal bebas sehingga berperan dalam mencegah terjadinya penuaan dini, kanker, dan penyakit-penyakit degeneratif.

\section{Antosianin}

Hasil sidik ragam menunjukkan bahwa perbandingan tepung beras dengan pasta ubi jalar ungu berpengaruh sangat nyata $(\mathrm{P}<0,01)$ terhadap kadar antosianin cendol ubi ungu. Tabel 3 menunjukkan antosianin cendol ubi ungu tertinggi diperoleh pada perlakuan P6 yaitu $1,37 \mathrm{mg} / 100 \mathrm{~g}$. Antosianin terendah diperoleh pada perlakuan P1 yaitu 0,16 $\mathrm{mg} / 100 \mathrm{~g}$ serta berbeda tidak nyata dengan perlakuan P2 dan P3. Peningkatan antosianin 
terjadi seiring dengan meningkatnya penambahan pasta ubi jalar ungu. Berdasarkan hasil analisis bahan baku (Tabel 2) antosianin ubi jalar ungu sebesar $4 \%$ sehingga semakin banyak konsentrasi penambahan ubi jalar ungu maka semakin tinggi pula antosianin yang terkandung di dalam cendol ubi ungu. Hasil penelitian ini sesua dengan penelitian Husna et al. (2013) yang menyatakan bahwa kandungan antosianin pada produk olahan ubi jalar ungu berkisar antara 1,14-2,24 mg/100g.

\section{Sifat Sensoris}

Pengujian sifat sensoris cendol ubi ungu dilakukan dengan uji hedonik dan uji skoring terhadap warna, aroma, tekstur, rasa, dan penerimaan keseluruhan. Nilai rata-rata uji hedonik terhadap warna, aroma, tekstur, rasa, dan penerimaan keseluruhan cendol ubi ungu dapat dilihat pada Tabel 4 dan nilai ratarata uji skoring terhadap warna, aroma, tekstur, dan rasa cendol ubi ungu dapat dilihat pada Tabel 5.

Tabel 4. Nilai rata - rata hasil uji hedonik warna, aroma, tekstur, rasa, dan penerimaan keseluruhan cendol ubi ungu

\begin{tabular}{cccccc}
\hline Perlakuan & Warna & Aroma & Tekstur & Rasa & $\begin{array}{c}\text { Penerimaan } \\
\text { Keseluruhan }\end{array}$ \\
\hline P1(50:50) & $3,80 \mathrm{e}$ & $5,00 \mathrm{~b}$ & $5,10 \mathrm{c}$ & $5,00 \mathrm{c}$ & $4,85 \mathrm{c}$ \\
P2(40:60) & $4,20 \mathrm{de}$ & $5,20 \mathrm{~b}$ & $5,10 \mathrm{c}$ & $5,00 \mathrm{c}$ & $5,20 \mathrm{bc}$ \\
P3(30:70) & $4,65 \mathrm{~d}$ & $5,35 \mathrm{~b}$ & $5,30 \mathrm{bc}$ & $5,20 \mathrm{c}$ & $5,20 \mathrm{bc}$ \\
P4(20:80) & $5,25 \mathrm{c}$ & $5,50 \mathrm{~b}$ & $5,70 \mathrm{ab}$ & $5,40 \mathrm{bc}$ & $5,65 \mathrm{~b}$ \\
P5(10:90) & $6,00 \mathrm{~b}$ & $6,20 \mathrm{a}$ & $6,15 \mathrm{a}$ & $6,05 \mathrm{ab}$ & $6,35 \mathrm{a}$ \\
P6(0:100) & $6,65 \mathrm{a}$ & $6,40 \mathrm{a}$ & $6,20 \mathrm{a}$ & $6,35 \mathrm{a}$ & $6,65 \mathrm{a}$ \\
\hline
\end{tabular}

Keterangan : Nilai rata - rata yang diikuti oleh huruf yang berbeda pada kolom yang sama menunjukkan berbeda nyata $(\mathrm{P}<0,05)$.

Tabel 5. Nilai rata - rata hasil uji skoring warna, aroma, tekstur, dan rasa cendol ubi ungu

\begin{tabular}{ccccc}
\hline Perlakuan & Warna & Aroma & Tekstur & Rasa \\
\hline P1(50:50) & $1,25 \mathrm{e}$ & $2,75 \mathrm{~b}$ & $3,30 \mathrm{~b}$ & $2,75 \mathrm{~d}$ \\
P2(40:60) & $1,70 \mathrm{~d}$ & $2,80 \mathrm{~b}$ & $3,35 \mathrm{~b}$ & $2,85 \mathrm{~cd}$ \\
P3(30:70) & $2,05 \mathrm{~d}$ & $3,05 \mathrm{~b}$ & $3,60 \mathrm{~b}$ & $2,90 \mathrm{~cd}$ \\
P4(20:80) & $3,00 \mathrm{c}$ & $3,10 \mathrm{~b}$ & $3,60 \mathrm{~b}$ & $3,30 \mathrm{bc}$ \\
P5(10:90) & $3,80 \mathrm{~b}$ & $4,05 \mathrm{a}$ & $4,10 \mathrm{a}$ & $3,65 \mathrm{~b}$ \\
P6(0:100) & $4,55 \mathrm{a}$ & $4,20 \mathrm{a}$ & $4,35 \mathrm{a}$ & $4,50 \mathrm{a}$ \\
\hline
\end{tabular}

Keterangan : Nilai rata - rata yang diikuti oleh huruf yang berbeda pada kolom yang sama menunjukkan berbeda nyata $(\mathrm{P}<0,05)$

Kriteria warna $\quad: 1$ (sangat ungu muda); 2 (ungu muda); 3 (ungu); 4 (agak ungu tua); 5 (ungu tua). Kriteria aroma dan rasa : 1 (sangat tidak khas ubi ungu); 2 (tidak khas ubi ungu); 3 (agak khas ubi ungu); 4 (khas ubi ungu); 5 (sangat khas ubi ungu).

Kriteria tekstur $\quad: 1$ (sangat tidak kenyal); 2 (tidak kenyal); 3 (agak kenyal); 4 (kenyal); 5 (sangat kenyal). 


\section{Warna}

Hasil sidik ragam menunjukkan bahwa perbandingan tepung beras dengan pasta ubi jalar ungu berpengaruh sangat nyata $(\mathrm{P}<0,01)$ terhadap warna (uji hedonik dan uji skoring) cendol ubi ungu. Tabel 4 menunjukkan bahwa nilai hedonik terhadap warna cendol ubi ungu tertinggi diperoleh pada perlakuan P6 yaitu 6,65 (sangat suka). Nilai hedonik warna terendah diperoleh pada perlakuan P1 yaitu 3,80 (netral) serta berbeda tidak nyata dengan perlakuan P2. Warna cendol ubi jalar ungu yang paling disukai panelis yaitu warna ungu tua.

Tabel 5 menunjukkan bahwa nilai skoring terhadap warna cendol ubi ungu tertinggi diperoleh pada perlakuan P6 yaitu 4,55 (ungu tua). Nilai skoring warna terendah diperoleh pada perlakuan P1 yaitu 1,25 (sangat ungu muda). Semakin banyak konsentrasi pasta ubi jalar ungu yang ditambahkan maka warna cendol yang dihasilkan semakin ungu tua, sebab ubi jalar ungu mengandung pigmen alami berwarna ungu yang dapat memberikan warna ungu pada cendol. Warna merupakan atribut kualitas yang paling penting dalam produk pangan karena walaupun suatu produk bernilai gizi tinggi, memiliki rasa yang enak, dan tekstur yang baik namun jika warnanya tidak menarik maka produk tersebut akan kurang diminati.

\section{Aroma}

Hasil sidik ragam menunjukkan bahwa perbandingan tepung beras dengan pasta ubi jalar ungu berpengaruh sangat nyata $(\mathrm{P}<0,01)$ terhadap aroma (uji hedonik dan uji skoring) cendol ubi ungu. Tabel 4 menunjukkan bahwa nilai hedonik terhadap aroma cendol ubi ungu tertinggi diperoleh pada perlakuan P6 yaitu 6,40 (suka) serta berbeda tidak nyata dengan perlakuan P5. Nilai hedonik aroma terendah diperoleh pada perlakuan P1 yaitu 5,00 (agak suka) serta berbeda tidak nyata dengan perlakuan P2, P3, dan P4. Aroma cendol ubi jalar ungu yang paling disukai panelis yaitu aroma khas ubi jalar ungu.

Tabel 5 menunjukkan bahwa nilai skoring terhadap aroma cendol ubi ungu tertinggi diperoleh pada perlakuan P6 yaitu 4,20 (khas ubi ungu) serta berbeda tidak nyata dengan perlakuan P5. Nilai skoring aroma terendah diperoleh pada perlakuan P1 yaitu 2,75 (agak khas ubi ungu) serta berbeda tidak nyata dengan perlakuan P2, P3, dan P4. Semakin banyak konsentrasi pasta ubi jalar ungu yang ditambahkan maka aroma cendol semakin khas ubi jalar ungu.

\section{Tekstur}

Hasil sidik ragam menunjukkan bahwa perbandingan tepung beras dengan pasta ubi jalar ungu berpengaruh sangat nyata $(\mathrm{P}<0,01)$ terhadap tekstur (uji hedonik dan uji skoring) cendol ubi ungu. Tabel 4 menunjukkan bahwa nilai hedonik terhadap tekstur cendol ubi ungu tertinggi diperoleh pada perlakuan P6 yaitu 6,20 (suka) serta berbeda tidak nyata dengan perlakuan $\mathrm{P} 4$ dan P5. Nilai hedonik terendah diperoleh pada perlakuan P1 yaitu 5,10 (agak suka) serta berbeda tidak nyata dengan perlakuan $\mathrm{P} 2$ dan P3. Tekstur cendol ubi jalar ungu yang paling disukai panelis yaitu tekstur kenyal. Tabel 5 menunjukkan bahwa nilai skoring terhadap tekstur cendol ubi ungu tertinggi diperoleh pada perlakuan P6 yaitu 4,35 (kenyal) serta berbeda tidak nyata dengan perlakuan P5. Nilai skoring tekstur terendah diperoleh pada perlakuan P1 yaitu 3,30 (agak kenyal) serta berbeda tidak nyata dengan perlakuan P2, P3, dan P4.

Tingkat kekenyalan suatu produk dipengaruhi oleh karbohidrat yang terkandung dalam bahan bakunya, yaitu amilosa dan amilopektin. Kandungan amilosa pada ubi jalar ungu sebesar 17,5-20\%, lebih rendah dibanding dengan kadar amilosa tepung beras yaitu $26,58 \%$. Semakin rendah kadar amilosa maka membuat tekstur semakin kenyal (Apriliyanti, 2010), sehingga semakin banyak 
pasta ubi jalar ungu yang ditambahkan maka membuat tekstur cendol semakin kenyal.

\section{Rasa \\ Hasil sidik ragam menunjukkan bahwa perbandingan tepung beras dengan pasta ubi jalar ungu berpengaruh sangat nyata $(\mathrm{P}<0,01)$ terhadap rasa (uji hedonik dan uji skoring) cendol ubi ungu. Tabel 4 menunjukkan bahwa nilai hedonik terhadap rasa cendol ubi ungu tertinggi diperoleh pada perlakuan P6 yaitu 6,35 (suka) serta berbeda tidak nyata dengan perlakuan P5. Nilai hedonik rasa terendah diperoleh pada perlakuan P1 yaitu 5,00 (agak suka) serta berbeda tidak nyata dengan perlakuan P2, P3, dan P4. Rasa cendol ubi jalar ungu yang paling disukai panelis yaitu rasa sangat khas ubi jalar ungu. \\ Tabel 5 menunjukkan bahwa nilai skoring terhadap rasa cendol ubi ungu tertinggi diperoleh pada perlakuan P6 yaitu 4,50 (sangat khas ubi ungu). Nilai skoring rasa terendah diperoleh pada perlakuan P1 yaitu 2,75 (agak khas ubi ungu) serta berbeda tidak nyata dengan perlakuan P2 dan P3. Semakin banyak konsentrasi pasta ubi jalar ungu yang ditambahkan maka rasa cendol semakin khas ubi jalar ungu.}

\section{Penerimaan Keseluruhan}

Hasil sidik ragam menunjukkan bahwa perbandingan tepung beras dengan pasta ubi jalar ungu berpengaruh sangat nyata $(\mathrm{P}<0,01)$ terhadap penerimaan keseluruhan (uji hedonik) cendol ubi ungu. Tabel 4 menunjukkan bahwa nilai hedonik terhadap penerimaan keseluruhan cendol ubi ungu tertinggi diperoleh pada perlakuan P6 yaitu 6,65 (sangat suka) serta berbeda tidak nyata dengan perlakuan P5. Nilai hedonik penerimaan keseluruhan terendah diperoleh pada perlakuan P1 yaitu 4,85 (agak suka) serta berbeda tidak nyata dengan perlakuan P2 dan P3. Nilai rata-rata penerimaan keseluruhan tersebut menunjukkan bahwa cendol ubi ungu dapat diterima dengan cukup baik oleh panelis.

\section{KESIMPULAN DAN SARAN}

\section{Kesimpulan}

Berdasarkan hasil penelitian yang telah dilakukan dapat diambil kesimpulan sebagai berikut:

1. Perbandingan tepung beras dengan pasta ubi jalar ungu berpengaruh nyata terhadap kadar air, kadar abu, kadar serat, dan berpengaruh sangat nyata terhadap aktivitas antioksidan, antosianin, dan sifat sensori yang terdiri dari warna, aroma, tekstur, rasa, dan penerimaan keseluruhan cendol ubi ungu.

2. Pembuatan cendol ubi jalar ungu tanpa menggunakan tepung beras menghasilkan karakteristik terbaik cendol ubi jalar ungu dengan karakteristik kadar air 89,47\%, kadar abu $0,14 \%$, kadar serat $1,44 \%$, aktivitas antioksidan berdasarkan nilai $\mathrm{IC}_{50} 93,42$ $\mathrm{mg} / \mathrm{mL}$, antosianin $1,37 \mathrm{~g} / 100 \mathrm{~g}$, warna ungu tua dan sangat disukai, tekstur kenyal dan disukai, aroma khas ubi ungu dan disukai, rasa sangat khas ubi ungu dan disukai, serta penerimaan keseluruhan sangat disukai.

\section{Saran}

Berdasarkan hasil penelitian ini disarankan untuk membuat cendol ubi jalar ungu tanpa menggunakan tepung beras.

\section{DAFTAR PUSTAKA}

Anonimus. 2017. Produktivitas Ubi Jalar Menurut Provinsi.Error! Hyperlink reference not valid. . Diakses tanggal: 23 Mei 2018.

Apriliyanti, T. 2010 . Kajian Sifat Fisikokimia dan Sensori Tepung Ubi Jalar Ungu (Ipomoea batatas blackie) dengan Variasi Proses Pengeringan . Skripsi S1 . Fakultas 
Pertanian . Universitas Sebelas Maret, Surakarta.

Candraningsih, F. 1997. Perilaku Konsumen Makanan Tradisonal Sunda (Studi Kasus di Rumah Makan Sunda Ponyo dan Bu Mimi, Kodya Bogor). Skripsi S1 . Fakultas Pertanian. Institut Pertanian Bogor, Bogor.

Chandra, A.A. 2008 . Kajian Pembuatan Cendol dari Beberapa Bentuk Sediaan Bahan Rumput Laut Eucheuma cottonii. Skripsi S1 . Fakultas Perikanan dan Ilmu Kelautan . Institut Pertanian Bogor, Bogor.

Direktorat Gizi, Departemen Kesehatan RI. 1979. Daftar Komposisi Makanan. Direktorat Gizi. Departemen Kesehatan RI. Jakarta.

Direktorat Gizi, Departemen Kesehatan RI. 2004. Daftar Komposisi Makanan. Direktorat Gizi. Departemen Kesehatan RI. Jakarta.

Ginting, E., J.S. Utomo, R. Yulifianti, dan M. Jusuf. 2011 . Potensi ubi jalar ungu sebagai pangan fungsional . Jurnal Ilmu Pengetahuan dan Teknologi Tanaman Pangan Vol. 6, No. 1.

Giusti, M. Monica dan R.E. Wrolstad, 2001, Characteristic and Measurement of Anthocyanins by UV-Visible Spectroscopy, Current Protocols in Food Analytical Chemistry, John Wiley \& Sons, Inc., F1.2.1-F1.2.13.

Gomez, K. A. dan A. A. Gomez. 1995. Prosedur Statistik untuk Penelitian Pertanian. (Terjemahan). E. Syamsudin dan J. S. Baharsjah. UI Press. Jakarta.

Hardoko, L. Hendarto, dan T.M. Siregar. 2010. Pemanfaatan ubi jalar ungu (Ipomoea batatas L. Poir) sebagai pengganti sebagian tepung terigu dan sumber antioksidan pada roti tawar. Jurnal Teknologi dan Industri Pangan 21 (1): 25 32.
Husna, N.E., M. Novita, dan S. Rohaya . 2013 - Kandungan antosianin dan aktivitas antioksidan ubi jalar ungu segar dan produk olahannya . Jurnal Agritech Vol. 33, No. 3.

Muchtadi, T.R., Sugiyono, dan Ayustaningwarno, F. 2010 . Ilmu Pengetahuan Bahan Pangan. Alfabeta, Bandung.

Novindar, M. 2010 . Uji Aktivitas Antioksidan Sirup Berbahan Dasar Rosela (Hibiscus sabdariffa) . Skripsi S1. Universitas Pendidikan Indonesia, Bandung.

Patmawati. 2011. Pengembangan Dessert Berbasis Isolat Protein Basah Ikan Lele (Clarias sp.) dengan Pewarna Alami. Skripsi S1. Fakultas Perikanan dan Ilmu Kelautan. Institut Pertanian Bogor, Bogor.

Soekarto, S. 1985 . Penilaian Organoleptik : Untuk Industri Pangan dan Hasil Pertanian. Bhratara Karya Aksara, Jakarta.

Sudarmadji, S., B. Haryono, dan Suhardi. 1997. Prosedur Analisa untuk Bahan Makanan dan Pertanian. Liberty, Yogyakarta.

Susilowati, E. 2010 . Kajian Aktivitas Antioksidan, Serat Pangan, dan Kadar Amilosa Pada Nasi yang disubstitusi dengan Ubi Jalar (Ipomoea batatas L.) sebagai Bahan Makanan Pokok . Skripsi S1 . Fakultas Pertanian. Universitas Sebelas Maret, Surakarta.

Ubaedillah . 2008 . Kajian Rumput Laut Euchema cottonii sebagai Sumber Serat Alternatif Minuman Cendol Instan. Tesis S2. Program Pascasarjana. Institut Pertanian Bogor, Bogor. 